\title{
PKM USAHA TELUR ASIN DESA PANGKUNG TIBAH KECAMATAN KEDIRI KABUPATEN TABANAN
}

\author{
PKM Salted Egg Business in Pangkung Tibah Village, Kediri District Tabanan Regency
}

\author{
Ni Kadek Sumiari ${ }^{*}$, Ni Luh Nyoman Mirah Wedasari ${ }^{2}$ \\ 1, 2 Jurusan Sistem Informasi, STMIK STIKOM Bali, \\ Jl. Raya Puputan No 86 Renon, Denpasar Bali, (0361) 244445 \\ *e-mail Korespodensi: sumiari@stikom-bali.ac.id
}

\begin{abstract}
ABSTRAK
Telur Asin merupakan salah satu makanan yang memiliki protein yang cukup tinggi. Selain mudah dikonsumsi, di Bali telur asin juga digunakan untuk membuat sesajen upacara. Jenis telur yang biasa digunakan untuk membuat telur asin adalah telur bebek. Telur bebek mempunyai tekstur kulit yang lebih mudah menyerap garam. Mitra yang akan dibantu dalam kegiatan ini adalah Ni Wayan Sukerni yang beralamat di Banjar Langudu Desa pangkung Tibah Kecamatan Kediri, Tabanan dan Ni Kadek Onik Setiarini Banjar Langudu Desa pangkung Tibah Kecamatan Kediri, Tabanan. Kedua mitra sudah menekuni usaha ini kurang leih 9 tahun. Saat ini kedua mitra masih memiliki kendala dalam menjalankan usaha mereka, diantaranya keterbatasan dalam alat produksi, kendala dalam memasarkan hasil produksi, belum memiliki desain kemasan produk dan juga kedua mitra belum memiliki pengetahuan tentang manajemen keuangan sehingga mitra tidak mengetahui jumlah keuntungan yang didapat secara pasti serta varian produk yang dihasilkan hanya satu yaitu telur asin. Berdasarkan kendala yang dihadapi mitra maka akan dilaksanakan kegiatan bertahap dimulai dari memberikan peralatan produksi, memberikan pelatihan mengenai manajemen keuangan serta pelatihan pengembangan produk berupa varian telur baru yaitu Telur Asin Bakar. Indikator capaian adalah peningkatan pendapatan mitra hingga 50\%, peningkatan jumlah produksi hingga 100\%. Dari pelaksanaan kegiatan yang telah dilakukan diperoleh hasil evaluasi kegiatan yaitu peningkatan jumlah produksi UKM sebesar 60\% serta produksi varian produk baru yaitu telur asin bakar. Dari hasil pelatihan manajemen keuangan satu anggota UKM telah bisa membuat buku khas keuangan sederhana. Pengemasan produk stempel lebih menarik dan mempunyai ciri khas dari UKM. Meningkatnya jumlah produksi juga mempengaruhi peningkatan jumlah pendapatan mitra yakni sebanyak 40\%. Kegiatan ini direncanakan berlangsung selama delapan (8) bulan dengan anggaran sebesar Rp. 40.000.000,--
\end{abstract}

Kata Kunci: Telur Asin, Peralatan Produksi, Manajemen Keuangan, Manajemen Pemasaran

\section{ABSTRACT}

Salted eggs are one of the foods that have high enough protein. Besides being easy to consume, in Bali salted eggs are also used to make ceremonial offerings. The type of egg used to make salted eggs is duck eggs. Duck eggs have a skin texture that absorbs salt more easily. The partners that will be assisted in this activity are Ni Wayan Sukerni having his address at Banjar Langudu, Pangkung Tibah Village, Kediri District, Tabanan and Ni Kadek Onik Setiarini Banjar Langudu, Pangkung Tibah Village, Kediri District, Tabanan. Both partners have pursued this business for less than 9 years. At present the two partners still have problems in running their business, including limitations in production tools, constraints in marketing their products, not having a product packaging design and also the two partners who have no knowledge of financial management so that partners do not know the exact amount of profits and only one product product variant is salted egg. Based on the constraints faced by partners, phased activities will be carried out starting from providing production equipment, providing training on financial management and product development training in the form of new egg variants, namely Salted Egg Egg. The achievement indicator is an increase in partner's income by $50 \%$, an increase in production up to $100 \%$. From the implementation of the activities that have been carried out, the results of the activity evaluation have been obtained, namely an increase in the number of SME production by $60 \%$ and the production of new product variants namely grilled salted eggs. From the results of the financial management training of one UKM member has been able to make a simple financial book. Packaging of stamp products is more attractive and has the characteristics of SMEs. The increase in the

Ni Kadek S, Ni Luh N. M. W., PKM USAHA TELUR... 
amount of production also affects the increase in the number of partners' revenues, namely as much as $40 \%$. This activity is planned to last for eight (8) months with a budget of Rp. 40,000,000

Keywords: Salted Eggs, Production Equipment, Financial Management, Marketing Management

\section{PENDAHULUAN}

Mitra dalam kegiatan Program Kemitraan Masyarakat ini adalah Ibu Ni Wayan Sukerni dan Ibu Ni Kadek Onik Setiarini. Kedua mitra memiliki usaha telur asin yang berasal dari desa Pangkung Tibah kecamatan Kediri kabupaten Tabanan Bali. Desa Pangkung Tibah merupakan desa pesisir selatan kabupaten Tabanan dan dapat dicapai dalam waktu 1 jam dari kota Denpasar.

Kedua mitra rata-rata sudah menekuni usaha telur asin lebih dari 9 tahun. Bahan baku yang digunakan oleh kedua mitra yaitu telur bebek diperoleh dari peternakan bebek di sekitar desa Pangkung Tibah, sedangkan untuk adonan pembungkus telur asin dibuat dari campuran tanah liat dan garam kasar. Tanah liat diperoleh oleh mitra di sekitar lokasi tempat tinggal mitra dan untuk garam kasar dibeli eceran di pasar terdekat. Proses produksi telur asin kedua mitra masih menggunakan proses secara tradisional. Dalam proses pembuatan telur asin, telur bebek mentah yang diperoleh oleh mitra pertama di lakukan pengecekan kualitas telur dengan menerawang telur di bawah cahaya matahari atau menggunakan senter. Telur dengan kualitas baik kemudian dipilih dan dipilah untuk dibuat telur asin. Setelah pemilihan telur kemudian dilakukan proses pembuatan adonan untuk membalut telur asin. Adonan dibuat dari tanah liat yang dicampur dengan garam kasar dan air secukupnya. Telur bebek yang sudah dipilih, dibalut dengan adonan tanah liat secara merata lalu diletakan dalam tempat penyimpanan dan disimpan dalam tempat tertutup selama $10-14$ hari. Setelah 10-14 hari telur asin yang masih mentah dicuci bersih lalu direbus hingga matang.

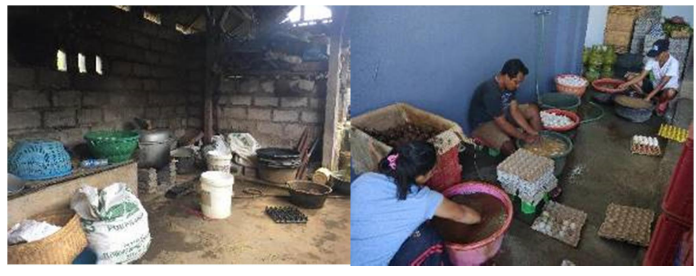

Gambar 1. Tempat kerja UKM Telur Asin

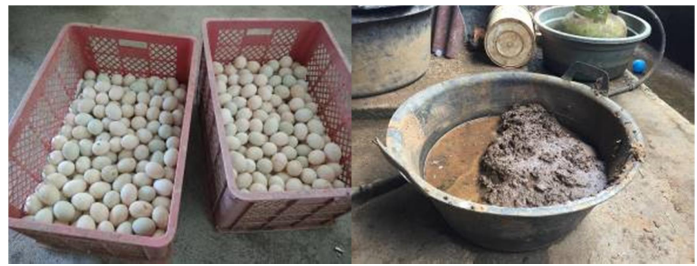

Gambar 2. Telur Bebek Sebagai Bahan Dasar Telur Asin

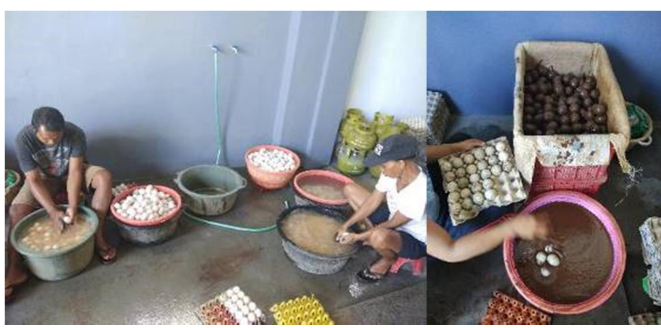

Gambar 3. Proses Pembuatan Telur Asin

Penjualan dan pemasaran telur asin kedua mitra dilakukan dengan cara menjual langsung ke pasar tradisional di Tabanan. Kemasan prosuk dari telur asin tidak memakai kemasan khusus hanya menggunakan baki telur dari kertas yang didapat dari pembelian telur bebek sehingga tidak tahan lama. Pengemasan yang kurang menarik juga membuat telur asin tidak bisa di pasarkan ke pasar-pasar swalayan. Kedua mitra juga tidak mengetahui secara pasti jumlah keuntungan dan kerugian yang mereka peroleh karena jaranng dilakukan pencatatan. Berdasarkan hasil wawancara yang dilakukan pendapatan yang diperoleh perbulan adalah sekitar Rp.2.400.000 
hingga Rp. 3.500.000. Produksi telur asin dilakukan setiap hari dengan jumlah produksi sekitar 400-500 butir tergantung dari permintaan dan ketersediaan bahan baku. Varian produk yang dihasilkan hanya satu produk yaitu telur asin matang dan belum dikembangkan ke produk telur lainnya karena kedua mitra tidak mengetahui informasi varian produk lain yang bisa dihasilkan.

Beberapa permasalahan yang dihadapi mitra adalah sebagai berikut:

1. Pendapatan mitra tidak menentu karena dipengaruhi oleh pesanan dari konsumen.

2. Apabila terdapat pemesanan langsung dari konsumen dalam jumlah banyak, mitra tidak dapat menyanggupi pesanan karena keterbatasan alat produksi yang dimiliki mitra dan juga keterbatasan modal.

3. Kemasan yang digunakan hanya menggunakan baki telur yang terbuat dari kertas, sehingga telur asin kurang tahan lama dan rentan pecah. Mitra belum mempunyai desain kemasan yang menarik untuk dipasarkan ke tokotoko atau swalayan.

4. Kedua mitra tidak melakukan pencatatan pendapatan dan pengeluaran, sehingga seringkali jumlah keuntungan yang diperoleh tidak diketahui dengan pasti.

5. Produk yang dihasilkan kedua mitra hanya satu produk karena kurangnya pengetahuan mitra tentang varian produk yang bisa dihasilkan dari bahan baku yang sama

Dari permasalahan diatas maka beberapa solusi yang dapat kami tawarkan pada kedua industri rumah tangga tersebut adalah:

a. Pemberian alat bantu produksi seperti kompor, panci, kontainer plastik untuk menyimpan hasil produksi yang lebih banyak.

b. Pemberian bantuan kemasan produk yang lebih menarik dan tahan lama serta pembuatan label yang menarik untuk telur asin sehingga bias di pasarkan ke swalayan-swalayan.

c. Pelatihan pengemasan dan desain label dari kemasan agar lebih menarik.

d. Pelatihan manajemen keuangan serta pencatatan pengeluaran dan pemasukan, sehingga dapat mengetahui keuntungan, kerugian, dan atau omset usaha.

e. Pemberian media pemasaran online berupa website pemasaran yang digunakan untuk menyampaikan informasi mengenai produk dan lokasi dari pembuatan telur asin.

f. Pelatihan pembuatan varian produk baru yaitu telur asin bakar. Bahan baku telur bitan hampir sama dengan telur asin biasa yaitu menggunakan telur bebek hanya berbeda di tahap akhir pembuatan dimana telur asin bakar melewati proses pembakaran terlebih dahulu. Telur asin bakar memiliki peluang yang cukup tinggi di pasaran karena selain harganya jauh lebih mahal peminatnya juga cukup banyak serta produksi telur asin bakar di Tabanan masih sangat jarang sehingga memiliki potensi cukup besar apabila diproduksi oleh mitra.

\section{METODE}

Ada enam bentuk kerja utama yang dilakukan, mulai dari sosialisasi, kemudian peningkatan kualitas serta jumlah produksi, pengemasan produk yang lebih menarik, pengelolaan keuangan, pengelolaan pemasaran dan yang terakhir evaluasi kegiatan. Prosedur kerja kegiatan ini ditunjukkan pada gambar berikut: 


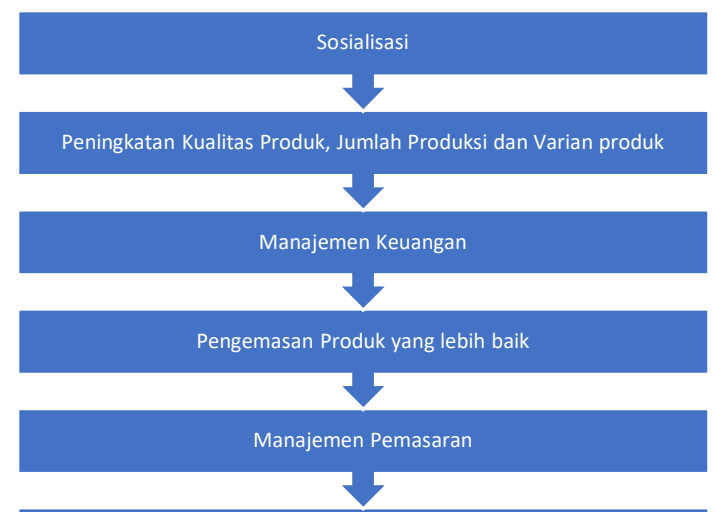

Evaluasi Kegiatan

Gambar 4. Prosedur Kerja Program Kemitraan Masyarakat

\section{Rencana Kegiatan}

Berdasarkan permasalahan mitra yang menjadi prioritas maka terdapat beberapa kegiatan untuk menangani permasalahan tersebut:

1. Sosialisasi dilaksanakan dengan menghadirkan peserta dalam pertemuan. Peserta adalah kedua mitra yaitu Ibu Ni Wayan Sukerni dan Ibu Ni Kadek Onik Setiarini. Pada pertemuan tersebut akan disampaikan informasi-informasi mengenai latar belakang, target, sasaran dan tujuan kegiatan. Disamping menyampaikan maksud dan tujuan, juga dilakukan pencatatan data teknis lebih lanjut serta pencatatan visualisasi dalam bentuk video dan foto. Dokumentasi ini digunakan dalam desiminasi atau pemasyarakatan hasil pelaksanaan program.

2. Pemberian alat untuk membantu dalam proses pembuatan produk serta pelatihan untuk varian produk baru. Pemberian alat berupa kompor yang lebih besar, keranjang plastic (rabbit container), panci serta alat-alat produksi yang bisa membantu dalam proses pembuatan produk yang lebih banyak. Selain itu juga diberikan pelatihan varian produk baru yaitu asin bakar dan diharapkan dengan adanya varian produk baru akan bisa meningkatkan penjualan dari mitra

3. Pelatihan dan bantuan sistem manajemen keuangan yang sederhana, yang dapat membantu mencatat bentuk dan jumlah pengeluaran serta pemasukan yang diperoleh. Diharapkan agar kedua mitra dapat mengetahui keuntungan atau kerugian yang diperoleh.

4. Bantuan pembuatan desain label yang menarik. Labeling akan didesain dengan menggunakan alat bantu komputer sehingga dihasilkan desain kemasan yang menarik dan eye catching serta modern. Serta pengemasan produk menggunakan kotak mika yang sudah diberi label sehingga produk bisa dipasarkan ke swalayan-swalayan.

5. Pelatihan dan bantuan sistem pemasaran yang lebih baik dan tidak hanya berfokus kepada menunggu pemesanan oleh pelanggan, namun juga secara proaktif melakukan pemasaran melalui website.

6. Evaluasi kegiatan pelatihan dilakukan setelah pelatihan manajemen dan pemasaran. Evaluasi kegiatan dilakukan untuk mengetahui keberhasilan kegiatan pelatihan yang dilaksanakan.

\section{HASIL DAN PEMBAHASAN}

\subsection{Realisasi Penyelesaian Masalah}

Sebagai bentuk inisisasi dari kegiatan PKM usaha telur asin di desa pangkun tibah Tabanan dilakukan sosialisasi ke UKM mitra untuk memberikan iformasi kegiatan PKM ini. Guna meningkatkan jumlah produksi dan pendapatan dari UKM Telur desa Pangkung Tibah Tabanan makan dilaksanakan kegiatan untuk menyelesaikan permasalahn yang ditemui oleh mitra yaitu dengan memberikan alat dan sarana untuk menujang produksi mitra seperti satu set 
kompor satu tungku, panci, rabit container dan alat pendukung lainnya. Selain itu untuk pengebangan produk mitra juga telah diberikan alat dan sarana untuk pengembangan produk baru yakni telur asin bakar berupa Oven Gas, serta telah diberikan pengetahuan tentang cara membuat varian produk telur asin bakar. Dari sisi kemasan untuk tahap awal mitra UKM telah diberikan desain stempel telur asin baru yang lebih menarik dan memiliki ciri khas dari UKM. Selain itu untuk mendukung kelancaran usaha dari mitra juga telah diberikan pelatihan manajemen keuangan dimana satu anggota dari UKM mitra telah memiliki kemampuan untuk membuat buku kas sederhana sehingga UKM mitra bisa melakukan pencatatan pengeluaran dan pemasukan dari UKM. Dengan kegiatan tersebut di atas SDM yang ada di UKM mitra dapat berkembang, produksi produk dapat meningkat serta adanya varian produk baru dimana berpengaruh pada pendapatan mitra menjadi semakin meningkat.

\subsection{Pelaksanaan Kegiatan}

Pelaksanaan kegiatan PKM Usaha Telur Asin di Desa Pangkung Tibah, Kediri Tabanan dilakukan selama 8 bulan dimulai dari bulan maret 2018 dengan tahapan sesuai dengan metode kegiatan yaitu sebagai berikut:

\section{a. Sosialisasi Kegiatan}

Pada tahap pertama kegiatan PKM Usaha telur Asin Desa Pangkung Tibah Tabanan dilakukan sosialisasi guna memberikan infrmasi mengenai Program PKM serta penentuan jadwal-jadwal kegiatan yang akan dilakukan dalam kegiatan PKM. Sosialisasi dilakukan pada bulan Maret 2018. Materi sosialisasi diberikan oleh ketua pelaksana yakni oleh Ni Kadek Sumiari dan anggota pelaksana yakni Ni Luh Nyoman Mirah Wedasari. Peserta dari sosialisasi ini adalah pemilik dari Usaha Telur Asin di desa Pangkung Tibah Tabanan yaitu UKM Telur Asin Ari yakni Ni Wayan Sukerni dan UKM Telur Asin Murni yakni Ni Kadek Onik Setiarini. Pada sosialisasi ini juga disampaikan latar belakang, target sasaran, tujuan serta indikator-indikator dalam melakukan kegiatan program PKM.

\section{b. Penyerahan Alat Produksi}

Berdasarkan permasalah yang telah dijabarkan sebelumnya serta hasil berdiskusi dengan UKM diperlukan beberapa peralatan untuk menunjang proses produksi UKM agar lebih meningkat. Pada bulan April dan Mei 2018 dilakukan penyerahan peralatan dan barang penunjang produksi UKM secara bertahap. Adapun bantuan berupa alat yang diberikan kepada UKM adalah sebagai berkut:

1. Kompor Gas satu tungku lengkap dengan selang, regulator dan tabung gas LPG $3 \mathrm{KG}$ digunakan untuk menunjang produksi mitra yakni untuk merebus telur asin

2. Peralatan dalam proses produksi telur asin seperti ember dan saringan besar untuk menunjang proses dalam membersihkan telur serta panci ukuran besar untuk merebus telur asin dalam jumlah banyak

3. Rabbit Container (Kontainer industri) tempat untuk menyimpan telur asin yang sudah jadi serta digunakan untuk prndistribusian telur asin ke penjual.

Keseluruhan barang penunjang produksi yang telah diberikan digunakan oleh UKM dalam menambah jumlah produksi karena keterbatasan alat atau untuk mengganti peralatan dan barang yang sebelumnya sudah tidak berfungsi lagi. Berikut merupakan dokumentasi dalam penyerahan peralatan dan barang penunjang produksi. 


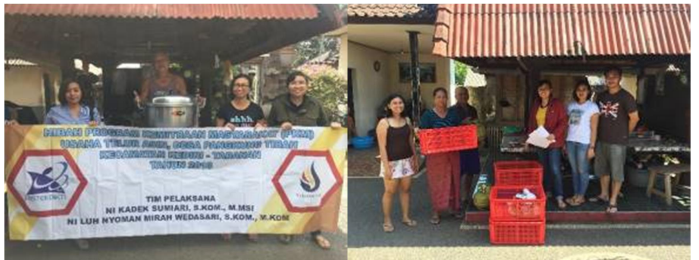

Gambar 5. Penyerahan Peralatan Penunjang Produksi Bagi UKM Telur Asin Murni Milik Ni Kadek Onik Setiarini

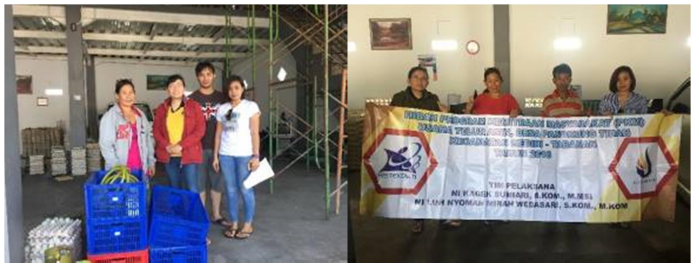

Gambar 6. Penyerahan Peralatan Penunjang Produksi Bagi UKM Telur Asin Ari Milik Ni Wayan Sukerni

\section{c. Desain Kemasan Produk}

Pada tahap ini dilakukan penyerahan barang penunjang produksi tahap berikutnya serta pemberian desain untuk stempel dan penyeraha stempel untuk telur asin. Selain meningkatkan proses produksi UKM juga perlu meningkatkan daya tarik dari sisi pengemasan produk yang dalam hal ini adalah telur asin. Stempel telur asin diperlukan sebagai penanda produk dan bisa menjadi ciri khas dari telur asin yang diproduksi oleh mitra. Pada tahap pemberian stempel telur asin sebelumnya dilakukan observasi kebutuhan desain stempel yang dikehendaki oleh UKM. Setelah desain yang diinginkan sudah pas maka baru dibuatkan stempel dan diserahkan ke UKM dusertai dengan tahap penyerahan barang lanjutan. Kegiatan ini dilakukan pada bulan mei 2018. Berikut merupakan dokumentasi dari kegiatan :

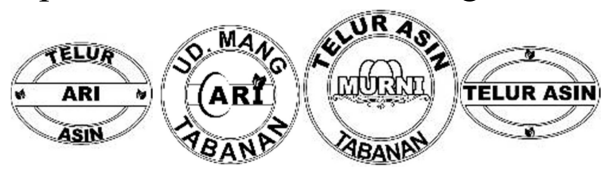

Gambar 7. Desain Stempel Telur dan Stempel Usaha Telur Asin Ari dan telur Asin Murni

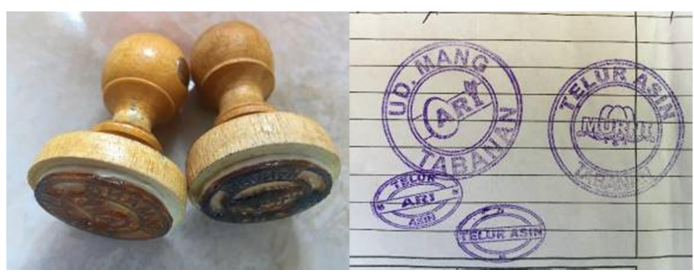

Gambar 8. Stempel Telur Asin dan Stempel Usaha Untuk UKM

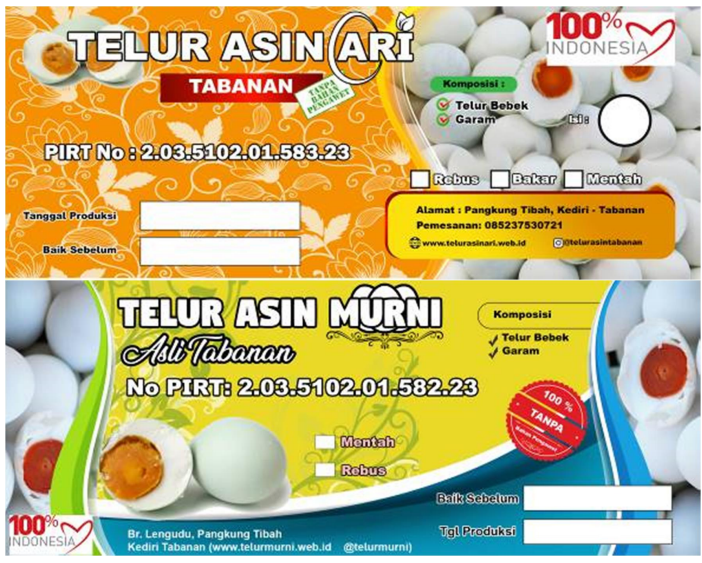

Gambar 9. Prototype Label Kemasann Telur Asin Ari dan Telur Asin Murni

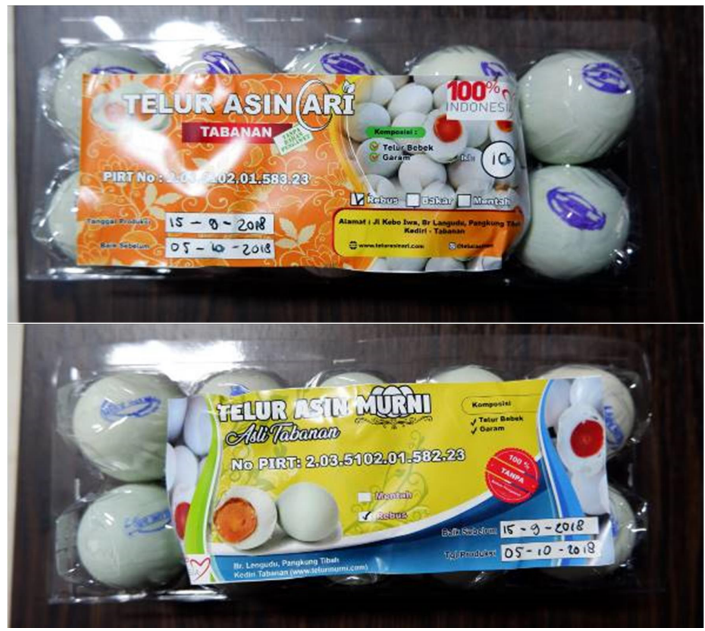

Gambar 10. Realisasi KemasanTelur Asin Ari dan Telur Asin Murni

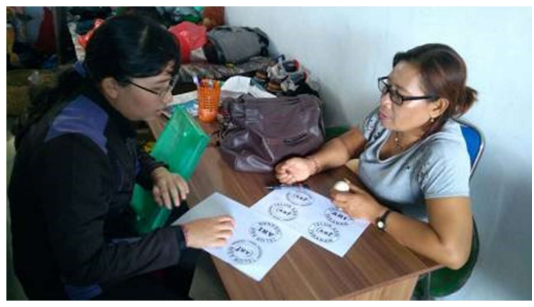

Gambar 11. Sosialisasi Desain Stempel UKM 


\subsection{Pelatihan Manajemen Keuangan}

Pada tahap selanjutnya kegiatan yang dilakukan adalah pelatihan manajemen keuangan. Pelatihan manajemen keuangan diberikan agar UKM dapat mengelola keuangan dengan baik. Dengan pengelolaan keuangan yang bagus maka UKM dapat melihat keuntungan dan kerugian yang dialami serta pengeluaran dan pemasukan dalam UKM dapat dicatat dengan baik. Pelatihan manajemen keuangan yang dilakukan adalah pelatihan manajemen keuangan sederhana menggunakan buku kas. Mitra dilatih untuk melakukan pencatatan pengeluaran dalam produksi, pembelian barang serta pemasukan yang dihasilkan. Dari pencatatan tersebut maka mitra dapat mengetahui keuntungan ataupun kerugian yang dieproleh. Berikut merupakan dokumetasi dari pelatihan manajemen keuangan :
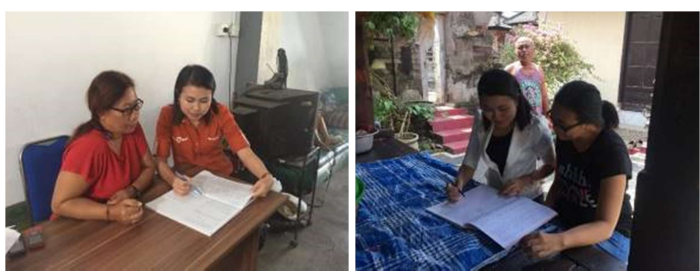

Gambar 12. Pelatihan Manajemen Keuangan Bagi UKM Telur Asin Ari dan UKM Telur Asin Murni

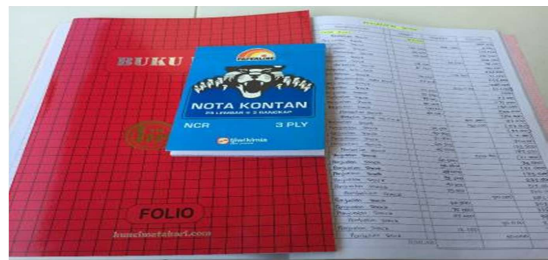

Gambar 13. Pelatihan Majanemen Keuangan Sederhana Bagi UKM

\subsection{Pelatihan Pengembangan Produk}

Untuk bersaing dengan pangsa pasar mitra juga harus melakukan pengembangan dalam jenis produk yang dihasilkan. Pada kegiatan ini mitra diberikan peralatan penunjang untuk pengembangan variasi
(Halaman 67-75)

atau jenis produk yakni produk dikembangan menjadi produk baru yaitu telur asin bakar. Peralatan penunjang yang diberikan adalah berupa Oven Gas yang digunakan untuk proses pembakaran telur asin. Pada kegiatan ini juga dilakukan implementasi alat, pelatihan cara penggunaan alat serta percobaan pembuatan telur asin bakar. Berikut merupakan dokumentasi dari kegiatan:

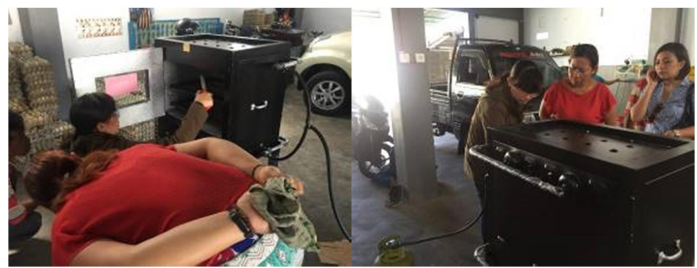

Gambar 14. Pemberian Alat Pengembangan Produk dan Pelatihan Penggunaan Alat

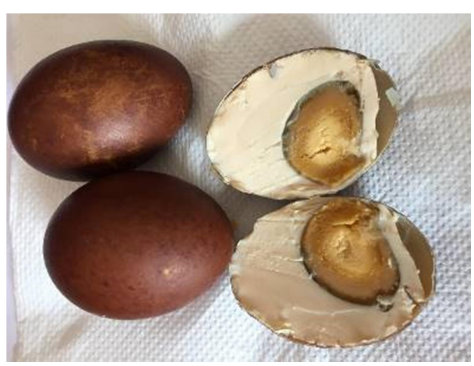

Gambar 15. Telur Asin Bakar

\subsection{Manajemen Pemasaran}

Tahap selanjutnya yaitu pembuatan media pemasaran produk dengan mengunakan website serta pemanfaatan media social sebagai media iklan untuk pemasaran produk telur asin. Media pemasaran produk online diberikan agar jangkauan pemasaran UKM yang selama ini terbatas bisa menjadi lebih luas. Selain itu dengan adanya perkembangan teknologi UKM diharapkan dapat memasarkan produknya ke area yang lebih luas. Mitra dibuatkan website informasi untuk publikasi produk secara online serta dibuatkan media social berupa Instagram untuk sarana iklan dari produk. 

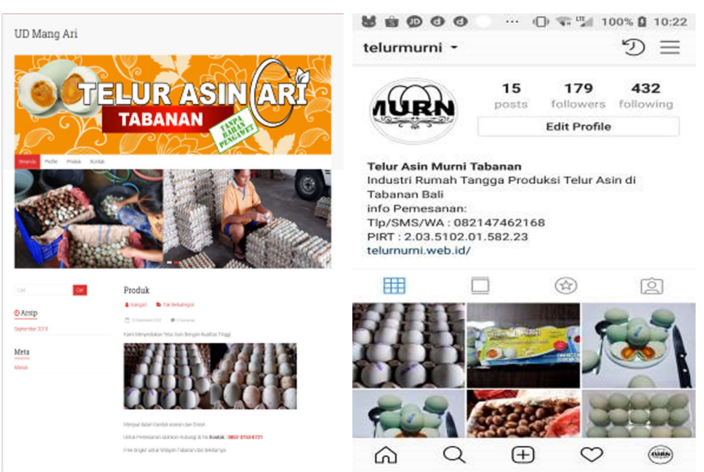

Gambar 16. Media Pemasaran UKM

\subsection{Evaluasi dan Monitoring}

Setelah pelaksanaan kegiatan maka dilakukan evaluasi dan monitoring kegiatan yang dilakukan oleh ketua dan anggota pelaksana kegiatan. Pada evaluasi dan monitoring dibahas mengenai pelaksanaan kegiatan program PKM Usaha telur asin di Pangkung Tibah Tabanan. Dari hasil monitoring yang dilakukan dapat disimpulkan pelaksanaan kegiatan program PKM telur asin di desa Pangkung Tibah Tabanan berjalan sesuai dengan rancangan kegiatan yang telah disepakati dengan mitra pada saat sosialisasi. Mitra merasa sangat terbantu dengan pemberian alat penunjang prosuksi. Mitra juga sangat antusias dengan pelatihan manajemen keuangan yang dilakukan serta sangat tertarik dengan rekomendari pembuatan varian produk telur asin baru yaitu telur asin bakar. Tim pelaksana memperoleh masukan dan pengetahuan dari mitra tentang rekomandasi varian produk lain yang memiliki proses produksi menyerupai telur asin seperti telur bitan, dan telur asin asap.

Berikut adalah rencara luaran kegiatan program PKM Usaha Telur Asin desa Pangkung Tibah Tabanan baik yang telah dilakukan pengukuran maupun yang akan dilakukan pengukuran. Luaran kegiatan yang diacapai ditunjukan pada table berikut:
Tabel 1. Pencapaian Luaran Kegiatan

\begin{tabular}{|c|c|c|c|c|}
\hline $\begin{array}{l}\mathrm{N} \\
\mathrm{o}\end{array}$ & Kegiatan & $\begin{array}{l}\text { Target } \\
\text { Luaran }\end{array}$ & $\begin{array}{c}\text { Indikator } \\
\text { Pencapaian }\end{array}$ & Capaian \\
\hline \multirow[t]{2}{*}{1} & $\begin{array}{l}\text { Penggunaan } \\
\text { Alat Penunjang } \\
\text { produksi }\end{array}$ & $\begin{array}{c}\text { Peningkatan } \\
\text { pendapatan } \\
\text { mitra dengan } \\
\text { menambah } \\
\text { jumlah } \\
\text { produksi }\end{array}$ & $\begin{array}{c}\text { Jumlah } \\
\text { produksi } \\
\text { dari mitra } \\
\text { meningkat } \\
\text { sebanyak } \\
60 \%\end{array}$ & $\begin{array}{c}\text { Evaluasi } \\
\text { diukur } \\
\text { setelah } 2 \\
\text { bulan alat } \\
\text { penunjang } \\
\text { produksi } \\
\text { digunakan } \\
\end{array}$ \\
\hline & & & $\begin{array}{l}\text { Pendapatan } \\
\text { dari mitra } \\
\text { juga } \\
\text { meningkat } \\
\text { sebanyak } \\
40 \% \text { dan } \\
\text { cukup } \\
\text { stabil }\end{array}$ & $\begin{array}{c}\text { Evaluasi } \\
\text { diukur } \\
\text { setelah } 2 \\
\text { bulan alat } \\
\text { penunjang } \\
\text { produksi } \\
\text { digunakan }\end{array}$ \\
\hline 2 & $\begin{array}{l}\text { Penggunaan } \\
\text { Buku Kas } \\
\text { dalam } \\
\text { Manajemen } \\
\text { Keuangan mitra }\end{array}$ & $\begin{array}{l}\text { Peningkatan } \\
\text { Manajemen } \\
\text { UKM }\end{array}$ & $\begin{array}{c}1 \text { orang } \\
\text { anggota } \\
\text { UKM } \\
\text { dapat } \\
\text { membuat } \\
\text { manajemen } \\
\text { keuangan } \\
\text { sederhana }\end{array}$ & $\begin{array}{c}\text { Setelah } \\
\text { dilakukan } \\
\text { evaluasi } 1 \\
\text { orang } \\
\text { anggota } \\
\text { dapat } \\
\text { membuat } \\
\text { buku kas } \\
\text { dan } \\
\text { pencatatan } \\
\text { order }\end{array}$ \\
\hline 3 & $\begin{array}{c}\text { Pengebangan } \\
\text { Varian produk }\end{array}$ & $\begin{array}{l}\text { Penambahan } \\
\text { produk dari } \\
\text { UKM }\end{array}$ & $\begin{array}{c}\text { UKM } \\
\text { berhasil } \\
\text { menambah } \\
\text { variasi } \\
\text { produk } \\
\text { yang } \\
\text { dihasilkan } \\
\text { yaitu tekur } \\
\text { asin bakar }\end{array}$ & $\begin{array}{c}\text { Evaluasi } \\
\text { akan } \\
\text { dilakukan 1 } \\
\text { bulan } \\
\text { setelah } \\
\text { penggunaan } \\
\text { alat }\end{array}$ \\
\hline 4 & $\begin{array}{c}\text { Media } \\
\text { Pemasaran } \\
\text { Produk }\end{array}$ & $\begin{array}{l}\text { Perluasan } \\
\text { Media } \\
\text { Pemasaran } \\
\text { UKM }\end{array}$ & $\begin{array}{c}\text { UKM } \\
\text { berhasil } \\
\text { menggunak } \\
\text { an media } \\
\text { online } \\
\text { sebagai } \\
\text { media } \\
\text { pemasaran }\end{array}$ & $\begin{array}{c}\text { Evaluasi } \\
\text { akan } \\
\text { dilakukan } 1 \\
\text { bulan } \\
\text { setelah } \\
\text { media } \\
\text { pemasaran } \\
\text { diberikan }\end{array}$ \\
\hline
\end{tabular}

\section{PENUTUP}

Berdasarkan kegiatan yang telah dilakukan maka dapat diperoleh kesimpulan sebagai berikut:

1. Program PKM ini sedang dilaksanakn untuk membantu UKM Telur Asin di Pangkung Tibah Tabanan dengan jenis kegiatan yang dilakukan adalah Pemberian peralatan penunjang produksi, pelatihan manajemen keuangan, pembuatan desain kemasan produk dan perlatihan serta pembuatan media pemasaran online.

2. Dari tahap awal kegiatan hingga sampai tahap akhir kegiatan ini, mitra sangat merasa terbantu dengan peralatan. 
3. penunjang yang diberikan serta sangat antusias dengan pelatihan yang diberikan. Mitra juga sangat atusias dengan kegiatan selanjutnya.

4. Penggunaan manajemen keuangan sederhana yakni menggunakan buku kas telah mencapai target yakni satu anggota UKM dapat melakukan pencatatan dengan buku kas.

5. Pembuatan dan pelatihan media pemasarn online untuk UKM berjalan dengan baik akan tetapi belum mencapai target karena belum bias di ukur dari sisi pemasran UKM.

6. Hasil evaluasi dari kegiatan jumlah produksi mitra meningkat sebesar $60 \%$ dan pendapatan mitra meningkat $40 \%$.

\section{UCAPAN TERIMAKASIH}

Dalam pelaksanaan Program Kemitraan Masyarakat (PKM) ini penulis banyak mendapatkan arahan dan bimbingan dari berbagai pihak. Dengan ini penulis ingin menyampaikan terima kasih kepada STMIK STIKOM Bali yang telah mendukung penulis dalam kegiatan PKM, untuk kedua Mitra yaitu Ibu Ni Wayan Sukerni dan Ni Kadek Onik Setiarini yang secara antusias telah ikut dalam pengabdian masyarakat ini serta semua pihak yang telah mendukung kegiatan ini

\section{DAFTAR RUJUKAN}

Andreas. 2011. Manajemen Keuangan UKM. Graha Ilmu.
Badan Pusat Statistik Kabupaten Tabanan. 2017. Kecamatan Kediri Dalam Angka . Online:

https:/tabanankab.bps.go.id/publication/ 2017/09/14/82b33d89065376432a536c3

e/kecamatan-pupuan-dalam-angka2017.html.

Badan Pusat Statistik Kabupaten Tabanan. 2018. Tabanan Dalam Angka. Online : https://tabanankab.bps.go.id/publication/ 2018/08/16/468aa965d1f1fad510484df3/ kabupaten-tabanan-dalam-angka2018.html.

Buku Masakan "Cara membuat Telur Asin Bakar" http://www.bukumasakan.com/carapembuatan-telur-asin-bakar-yangsangat-enak-dan-gurih-sekali/ diakses tanggal 01 Juli 2018.

Eri Bowo \& Kurniawan.2009. Template CMS : Panduan Mudah Membuat Template Joomla, Drupal, WordPress \& Dotnet Nuke. Jasakom.

Rahmawati, Bramantika Oktaviani, \& Muh. Djamal. Strategi Pemasaran UKM Melalui Program CSR di Perbatasan Kalimantan Utara.

Wikipedia, "Telur Asin", https://id.wikipedia.org/wiki/Telur_asin Diakses tanggal: 02 Juni 2017, pukul 09.00wita. 
